Mid-American Review of Sociology

Homans, George. 1984. Coming to My Senses: The Autobiography of a Sociologist. New Brunswick, NJ: Transaction.

Meyer, John W. and W. Richard Scott. 1983. Organizational Environments: Ritual and Rationality. Beverly Hills, CA: Sage.

Riley, Matilda W., ed. 1988. Sociological Lives. Newbury Park, CA: Sage.

Scott, W. Richard. 1970. Social Processes and Social Structures. New York: Holt, Rinehart, and Winston.

. 1987. Organizations: Rational, Natural, and Open Systems. 2nd ed. Englewood Cliffs, NJ: Prentice-Hall.

Whitehead, Alfred North. 1925. Science and the Modern World. New York: MacMillan.

\section{A ROAD WORTH TAKING: SOCIOLOGY AS A VOCATION AND THE LEGACY OF CARROLL D. CLARK*}

Gary Foulke

University of Kansas

Mid-American Review of Sociology, 1991, Vol. XV, No. 2:43-57

The meaning of sociology as a vocation, as seen through the career of Carroll D. Clark, is the focus of this paper. As the chairperson of the Department of Sociology at the University of Kansas for over three decades, Clark had an extraordinary influence on the shape of the department at Kansas and the discipline in the Midwest. Through an examination of his career at Kansas, it is shown that sociology for Clark was indeed a calling a calling to which he devoted passionate enthusiasm and unwavering commitment. Also explored is Clark's role as a public intellectual.

As the discipline of sociology moves into its second century in the United States it is appropriate, indeed incumbent upon present-day sociologists to take stock of where we have been. While the discipline has grown and changed in myriad ways, the questions that each sociologist must face have in certain respects remained the same. The question that this paper will attempt to deal with is the question of sociology as a vocation. How has the meaning of the vocation changed for sociologists over time?

In attempting to answer this question, it is fruitful to look at the lives and careers of sociologists to see how the idea of vocation is reflected in their work. The opportunity to ascertain what sociology has meant to others in the past can help give perspective to the role of the sociologist today. In 101 years at the University of Kansas, the department of sociology has seen the tenure of many outstanding faculty, including Ernest Burgess, Loren Eiseley and Seba Eldridge. Yet Carroll Clark is one individual who consistently stands out in the history of the Kansas department.

*Discussions with E. Jackson Baur, Charles Warriner and Norman Yetman provided significant insights for this paper, for which I thank them. I also thank David Norman Smith and Laura Z. Barter for their helpful comments, and the staff at the University Archives, University of Kansas, for their assistance in preparing this paper. 
An important way in which Clark contributed to the discipline was through his participation as a "public intellectual." Russell Jacoby (1987), in his book The Last Intellectuals, laments the retreat of intellectuals to the safe and isolated confines of universities. Rather than engaging in public discourse about social issues, intellectuals today tend to write for a small community of academicians (Jacoby 1987; see also Mills 1963; Goldsen 1964). Clark was not a part of this "intellectual retreat" (Mills 1963); throughout his career, Clark was a public intellectual. Clark actively participated in public discourse through his teaching, public lectures and his radio shows on sociology and jazz music.

The career of any individual sociologist, especially one with such wideranging contributions as Clark, could never be adequately summarized in the short space of an article. ${ }^{1}$ Indeed, Clark himself was aware of the daunting nature of such a task. In his address at the 25th meeting of the Midwest Sociological Society (MSS), an organization which he helped found, Clark was asked to give an overview of the history of the MSS. Documenting the development of such an organization was a huge task, let alone documenting the development of the individual sociologists who made up the organization: "To account for the genesis of any sociologist is difficult enough, for one must unravel a complex life history to show why a given neonate will grow up to follow our strange calling" (Clark 1962). This paper will show, after a brief biographical sketch, how Clark's interests in newspapers, radio and jazz music contributed to his role as a public intellectual. Further, an analysis of his activities as chairperson of the sociology department will provide significant insight into the meaning of sociology as a vocation.

\section{ORIGINS OF A "MARGINAL MAN"}

Carroll DeWitt Clark (1898-1978) was born and raised near Minneapolis, Kansas, a small farming community in the north-central part of the state. His father and grandfather were both "horse and buggy" doctors and over several decades were responsible for delivering most of the babies in the area, including Clark himself. Being raised on a farm was an important aspect of his childhood. His family raised milk cows in the days before milking machines, and Clark humorously notes the "influence that a bunch of bovines can exert on a person's destiny" (Clark 1970).

His parents' decision to send their children to the town school in Minneapolis rather than the country school was an important decision, according to Clark. Clark admits he was an average student in grade school, but he pressed on until he received his high school diploma. Even though a high school education was seen as "more than enough" education in those days, Clark chose to attend the University of Kansas after a stint in the Army. Clark served in France during World War I, though he did not see any combat, and he later served during World War II in a state-side training position (Clark 1968, 1970).
Clark referred to himself as a "marginal man" (Clark 1970). This notion took hold of Clark as a child, as he felt his family was "marginal" in that they had "one foot in the country subculture and one foot in the town subculture" (Clark 1970). This feeling of being "on the fringe" continued for Clark as an undergraduate at The University of Kansas in 1919. Clark noticed a distinct division between students in fraternities and sororities (the "Greeks") and everyone else (known as the "barbarians"). Clark chose to be a barbarian. The campus class system was in large part shaped by this division; Clark, fresh from his hitch in the Army, did not relish the notion of living under the stultifying conformity required by the fraternities. Freshmen at that time were required to wear caps, or "beanies", at all times or risk an encounter with a "paddle squad" of juniors and seniors. Clark refused to wear his beanie all the time, though he did carry it in his pocket so that he "could don it whenever a gang of tradition-enforcers came in view" (Clark 1968).

As an undergraduate, Clark followed his interests in journalism, which had been fostered by a job at his home-town newspaper. In 1920, however, he enrolled in Delbert Mann's Elements of Sociology course and found an intellectually challenging arena for his evolving interests in social issues. Sociology won out over journalism for Clark, though his interest in journalism and newspapers continued for some time, as evidenced by his early publications (Clark 1926a, 1933a, 1934). Clark continued at Kansas until he obtained the Master's degree in 1925. During this time he began to solidify some of his contacts with the department and developed friendships which would prove to be a strong factor in his decision to return as a faculty member. Clark was a full-time instructor in the department from 1925-1927, and attended the University of Chicago from 1927-1929.

His first teaching experience was totally unexpected. As an M.A. student at Kansas in 1924, Clark was enrolled in Frank W. Blackmar's course, General Anthropology. ${ }^{2}$ According to Clark, Blackmar was sick of teaching the course and simply quit coming to class. The members of the class muddled along trying to keep up with the reading, and were dismissed each day by a staff member. After a week and a half had passed the acting chairperson, Stuart A. Queen, pulled Clark aside and told him, "It's yours from now on." "My what?" Clark asked. "General Anthropology," Queen replied. Thus, for the remainder of the semester Clark was the instructor for a course in which he was enrolled! Clark knew very little about anthropology at that time, but with a lot of extra work during the weekends he was able to survive the semester. The most difficult aspect of this situation for Clark occurred when the end of the semester rolled around, and grades had to be assigned for his peers (and himself). After talking it over with his wife and the chairperson, Clark decided that if he was qualified to teach the course then he deserved an "A." However, when he eventually received his grades for the semester, Clark was surprised to find that his grade for General Anthropology was a "B," presumably changed by the dean of the graduate school. This grade was the only " $\mathrm{B}^{\prime \prime}$ to mar his record as a graduate student (Clark 1965a). 
There is little record of Clark's experiences as a Ph.D. student at the University of Chicago between 1925 and 1927. It is known that he studied inder many of the important figures in the Chicago school, including George Herbert Mead, Edward Sapir, Ellsworth Faris, Ernest Burgess and his mentor, Robert E. Park. His dissertation, entitled "News: A Sociological Study" was finished hurriedly after he came to Kansas in 1931. The Kansas administration was anxious to see Clark receive his Ph.D. as soon as possible, and therefore Clark was not able to revise and polish the manuscript as much as he would have liked. Because of the depression, Clark was never able to publish his dissertation in book form (Clark 1931; Park 1933).

The influence of Mead on Clark was particularly strong, and according to Charles Warriner, Professor Emeritus of Sociology at Kansas, this influence was reflected in Clark's attitudes towards others: when Clark dealt with problems he tended to "judge the action and not the actor." As a Meadian, Clark provided insights into social psychology that were to have a significant influence on his peers as well as his students.

\section{RADIO DAYS AND THE JAZZMAN}

Throughout his tenure in the sociology department, Clark continued the "public intellectual" tradition started by Blackmar of disseminating social science knowledge to the general public. Blackmar was widely known for his lectures on social science and education, as he delivered numerous lectures to adult audiences in Lawrence, Kansas City and the surrounding area (Clark 1965b; Sica 1990). During much of his career Clark gave several lectures a year to audiences outside the university.

Considering his interests in journalism and mass communication, it is not surprising that when the opportunity arose to communicate social science to a wider audience, Clark took advantage of it. Between 1951 and 1954 Clark hosted a radio program broadcast over a local station called "Sociology on the Air." At that time it was a fairly bold and successful experiment, as it was the only regular sociology broadcast over a commercial station in the country. Heard in four states on Sundays during the school year; the program featured presentations and round-table discussions with faculty, administrators and prominent campus visitors. Program topics included, "The Business of Growing Up in a Democracy," "The Challenge of Rural Life," Population Trends in the Middle West," and "Vocational Opportunities in Sociology" (Clark 1954).

A 1952 broadcast featured a presentation by Clark on "Citizenship," a topic which Clark returned to in various ways during his career (see, for example, Eldridge and Clark 1928; Clark and Roberts 1936; Clark 1952). The following excerpt from Clark's address on citizenship provides insight into his views on education and the average citizen.

Looking at him either individually or in the mass, our common or garden variety of citizen is no superman. His critics find him to be dull-minded, lethargic and gullible. He is more interested in the sports page and the comics than in serious editorials on important economic or political questions, and prefers Bob Hope and Hopalong Cassidy to the wisest commentator on the news. In cigar stores or the Pullman lounge we hear him arguing stubbornly from premises all experts agree are fallacious. Nevertheless, nothing is easier than to sell him short, and that is what intellectual critics are constantly prone to do. What the common man as citizen possesses--and what intellectuals too often lack--is a relaxed, dispersive mentality capable of reducing complex situations to a few fundamentals and arriving at an effective syncretistic judgement. Syncretistic thinking, as used by Piaget and Mayo, is a term hard to define, but it means about the same thing as what the generation of David Harum called horse sense." As it operates in public opinion--the collective deliberative processes of a free society--the syncretistic thinking of common citizens derives some measure of perspicacity from the richness and diversity of contemporary community life. Even so, the quality of our citizenship leaves much to be desired. Preparation for active, informed, and responsible citizenship is the foremost job of general education (Clark 1952).

Clark was, according to all accounts, a fine saxophone player. One colleague remarked at the time of Clark's retirement that he considered Clark to be "a top-flight alto sax man who moonlights as a sociologist" (McCluggage 1968). Clark never had any formal lessons, and being self-taught he considered his playing style to be somewhat unorthodox. As an undergraduate at KU, Clark played the saxophone not only for enjoyment but for his meals (Clark 1968). After his return to $\mathrm{KU}$ as a faculty member, he ceased playing the saxophone for a number of years because jazz was, at that time, an unseemly avocation for a university professor. He sold his saxophone (which reportedly had belonged to a member of the Ringling Brothers circus at one time) in the early 1930 s and only years later, in 1941, did he begin playing in public again. Cläk became à member of an informal group of academicians at the University who periodically got together for "jam sessions" and occasionally played at the Kansas faculty club (Clark 1959).

His love for jazz was such that he hosted a local radio show on jazz between 1957 and 1959. In the two years that he hosted the show, called "A Professor Looks at Jazz," Clark informed his listeners about the history and significance of jazz as a form of music and occasionally be played on the air with his group of fellow academics/musicians (Clark 1959). In addition, he was well-known for his playing at the Midwest Sociological Society meetings with other "moonlighters" such as Howard Becker (McCluggage 1968). 


\section{THE NEW REPUBLIC CONTROVERSY}

The January 20, 1926 issue of The New Republic featured an article by Clark (1926a) which prompted a considerable amount of controversy. The fallout over this particular article was a small part of Clark's personal history, but it does provide insight into the direction of Clark's interest in social issues as well as his personal sense of responsibility as a public intellectual.

The major impetus for the controversy caused by Clark's article was the title, which was written by the editors of The New Republic and not by Clark himself. In the table of contents on the cover of the issue, the article is listed as "The Small Town Newspaper, by Carroll D. Clark." However, the title of the article accompanying the text was the more sensationalized "The Small Town Press Sells Out," a title which Clark said added fuel to the controversy (Clark 1926b).

The main point of Clark's article was that, despite popular notions to the contrary, small town newspapers were becoming just as susceptible to influence from outside interests as larger metropolitan news organizations. In support of this notion, Clark offered four main points: an increase of "good will" advertising by large corporations and utility companies, most of which had no direct interest in the small community; an increasing use by small papers of "boilerplate" and syndicated material instead of original news stories; an increase in news articles which were nothing more than "thinly-veiled propaganda;" and finally a noticeable decrease in the "personality" of the articles, for traditionally the editor spiced up the accounts of the otherwise mundane local happenings. Clark sums up his argument with the following:

That there is still a function for the small press, few students of rural problems will deny. There is a great need for an indigenous agrarian leadership possessed of critical intelligence and a knowledge of relevant social, economic and political facts. With a few notable exceptions, rural journalists are not contributing such leadership. Where there is an editorial policy at all, it bears little relation to the vital problems confronting the rural population of the Middle West today (Clark 1926a).

In the ensuing weeks Clark was frequently criticized in editorials by publishers and editors who thought that Clark was attacking the rural press as an institution, whereas he was actually criticizing trends which he saw as destructive to the credibility of the small town newspaper. Queen was responsible for deflecting much of the "heat" generated by this controversy (Clark n.d.). However, several Kansas newspaper editors, including William Allen White, did come to his defense (White 1926).

Considering Clark's background and interest in journalism, it is understandable that he was somewhat taken aback at the criticism he received. In a personal correspondence to an editor who had scathingly criticized the article, Clark writes: "...I can't help being indignant when 1 see these outside interests using the small town press for their own ends.... I have genuine affection for the Kansas press--that is why I am criticizing its policy" (Clark 1926c).

\section{CLARK AS CHAIRPERSON}

In 1929 Clark was working at the University of Connecticut (then known as Connecticut Agricultural College) as an Associate Professor of Sociological Research. Due to the departure of a colleague at Connecticut, Clark stood a good chance of becoming head of the Sociological Research department at Connecticut, with the possibility of a substantial raise as well (Clark 1929a). It was during this year that Cint - sceived an offer from Queen at Kansas, an offer that he would tir

Queen, who was leaving Kansas the following year to take a research position in Detroit, wrote to Clark saying that Chancellor Lindley had spontaneously brought up Clark's name as a suitable successor for chairperson (Queen 1929). Clark's strong personal ties to the Kansas department proved to be the deciding factor in his decision to come back to Kansas, though his starting salary of $\$ 2800$ was considerably less than he might have earned had he stayed at Connecticut (Clark 1929b). Clark's first semester teaching load after he returned to Kansas in 1931, which was reduced because of his duties as acting chair, included the following: General Anthropology ( 3 credit hours); Social Pathology I ( 3 credit hours); Elements of Sociology ( 5 credit hours); and the graduate-level research methods course called Seminar on Social Investigation (2-4 credit hours) (Queen 1930)

Clark was chair of the department of sociology from 1933 until 1962, when university age regulations forced Clark to resign his duties as chairperson. Clark continued to teach until 1965 . Counting his two years as acting chair before his promotion to full professor in 1933, Clark was chair of the department for 31 years.

Holding the chair for such a long time is an important factor to consider when studying Clark's career. Indeed, it has been noted that while Clark was a productive scholar in terms of published work, he most certainly would have produced more had he not been burdened by the duties of chair for such a long time (Gist 1968). His commitments to the department, to the university and to the state of Kansas proved to have, to a certain degree, constraining effects on his own career. Over the years Clark received numerous offers to go elsewhere, and he did hold several brief visiting professorships over the years, but his ties to Kansas and his commitment to the department kept him from leaving.

According to Warriner (personal communication), Clark was intellectually productive even though this did not show in his publication record; it showed in the classroom and was especially noticeable in one-on-one discussions. Like his mentor at Chicago, Robert E. Park, Clark made many of his "intellectual contributions" in the classroom (Gist 1968; Weber 1968). Warriner states that Clark was a "classic" intellectual: 
What impressed me about Carroll was that he was an intellectual. He was an intellectual in the sense that he approached problems and issues not from an emotional basis but from a reasoned point of view. He was committed to the world of ideas. He was practical, but I think it was the world of ideas that was really important to him.

Why was Clark chair for so long? The answer to this question seems clear: he was good at it. He was a strong leader and he led by example. He had high expectations of himself, and expected a great deal of his colleagues as well. He was extremely well-liked and well-respected by his colleagues, the administration, and his peers across the Midwest (Gist 1968; McCluggage 1968).

A structural factor which complicated the situation in the Kansas department was the fact that for many years, social work and anthropology were also part of the department. As a sociologist Clark definitely emphasized his own discipline in the departmental structure, but he was also supportive of social work and anthropology. In 1946, Esther Twente, with considerable support from Clark, founded the school of social work at Kansas (Patterson and Zimmerman, 1987). Anthropology continued to co-exist with sociology until 1964, when the anthropologists formed their own department. Clark was supportive of their move for two reasons. First, he recognized the importance of anthropology as a distinct academic discipline, even though anthropology was one of his long-time teaching interests. Second, Clark realized that a continued linkage of sociology and anthropology, with limited university resources and space, would act as a constraint upon both departments (Clark 1965a).

It is important to note that the administrative structure of the University of Kansas during much of Clark's tenure was considerably different than it is today. For example, there were fewer administrative offices and administrators to deal with, partly because the university was still fairly small. Until the late 1950s, there was considerable direct correspondence between Clark and the Chancellor of the university. When members of his department needed items such as maps, file cabinets or skulls (for the anthropologists in the department), Clark would make his budget requests by memorandum directly to the Chancellor's office. Overall, the university was much more of a gemeinschaft organization during Clark's tenure than is true today. ${ }^{3}$

Clark was the guiding force behind the structure of the department, especially in terms of adding new personnel. As a Chicago graduate himself, Clark was largely responsible for the Chicago "pipeline" which developed during the first half of the century (Sica 1983). Although not totally wedded to the idea of hiring only Chicago Ph.D.'s, as evidenced by the fact that not everyone in the KU department had a Chicago Ph.D., Clark frequently relied on his connections at Chicago to secure many of the most important faculty members in the Kansas department (E. Jackson Baur and Warriner, for example). Most of the sociologists in the department during Clark's tenure were either Chicago. Ph.D.'s or had "taken work" at Chicago, while the anthropologists came from a more diverse set of institutions.

In addition, the decision-making structure of the sociology department was considerably different than it is today. When Clark joined the department in 1931, there were only five full-time professors in the department, and the university served 5,685 students. By 1968, there were 15 full-time professors in the department (down from a high of 20 before anthropology became a separate department), and the university had grown to over 19,000 students. Thus, Clark guided the department through a period of tremendous growth and had an extraordinary influence upon the shape of the department.

Partly as a function of its size, the department was run in more of an autocratic fashion during Clark's tenure than it is today. According to Baur, Professor Emeritus of Sociology at Kansas (personal communication), decisions that are today made by committees used to be made solely by the chair. Hiring decisions were made not by a personnel committee but by the chairperson; textbooks were not chosen exclusively by the instructor but in consultation with the chairperson. In this sense it can be said that Clark ran the department from his "hip pocket."

Not only was Clark a strong supporter of his own department, but he was also very involved in the mission of the university as a whole. For example, during the lean financial times of the 1930s, when everyone at the university was taking salary cuts, Clark was doing his part to save the university money. In 1932 faculty cou!d turn in travel vouchers and expect to be reimbursed at the rate of 5 cents per mile. Through Clark's encouragement, the faculty of the sociology department turned in their travel vouchers at the previous rate of 4 cents per mile. A 1932 memo from the Chancellor asked why the department had not been returning vouchers at the standard rate and stated that henceforth, travel vouchers would only be honored when turned in for the standard rate of 5 cents per mile (Lindley 1932). In his reply to the Chancellor, Clark explains why his department had not been following procedure on this matter: "I mention this because I thought you might be interested to know of definite instances where staff members are co-operating to effect economies in this emergency situation" (Clark 1932).

Clark was, according to Baur and Warriner, a very skilled chairperson. He chose new faculty members in the department with many objectives, not the least of which was to maintain a cordial and professional working atmosphere. That is not to say he didn't have personnel problems. On more than one occasion Clark had to come to the defense of his friend and colleague Seba Eldridge, who was frequently in hot water with local politicians and the local press (Sica 1983). Eldridge, according to Warriner, was "an avowed socialist in a day when it was really dangerous to be a Democrat in Kansas." Clark's skills as a mediator and a facilitator sharpened over the years as he dealt with the problems of the department and the university.

One of his first real dilemmas as chair had to do with the case of Mabel Elliot (see Stephanne L. Zale's article in this issue of MARS for more on the career of Elliot). The depression had forced departments to cut back in many 
ways, and the most problematic method was cutting salaries. Clark spent many sleepless nights when he was forced to inform his already underpaid colleagues that their salaries would be cut by 25 percent. In the fiscal crisis of 1933 Clark found himself in something of a quandary, because not only was he forced to tell his colleagues about their cuts in salary, but he was forced by the Kansas administration to reduce one faculty member of the small department to half-time.

Elliot, the only female faculty member in the department, did not "get along" with most of the other members of the department, especially her older colleagues. In addition, she missed many class sessions due to, in the words of her physician, "hypochondriacal ailments." Between 1936 and 1941 Elliot missed an average of 26 class sessions per semester because of various healthrelated reasons, and Clark and his colleagues were hard pressed to fill-in on such a regular basis (Clark 1974). In a 1937 letter to Queen, Clark expressed his reservations about the unrest in the department which Elliot was causing.

I do not believe that the situation grows out of the fact that she is a woman (except as it effects Mr. Helleberg, whose judgement I do not accept in such matters) but rather from certain personality characteristics, such as extreme aggressiveness, obtrusiveness, tactlessness, and egotism. Over against these traits she has displayed, in my judgement, many fine qualities, including a conscientious attitude toward her work, great energy, and enthusiasm. Gradually and reluctantly, however, I have been forced to conclude that she is incapable of fitting into the departmental scheme, and is a serious barrier to esprit and harmony (Clark 1937).

Elliot was reinstated to full-time status in 1936, and surprisingly she stayed at the University of Kansas until 1947. Clark did his best to keep Elliot and the other faculty in the department happy. However, according to Clark, Elliot proved to be a persistent "unsettling influence" in the department for many yèars (Clark 1974).

A latent function of being the chairperson was to field various sorts of inquiries and provide information to individuals and agencies. During the 1930s, Clark corresponded a great deal with officials in the Works Progress Administration, the Kansas Emergency Relief Committee, and various community agencies throughout the state. Because of his book, People of Kansas (1936), co-authored with Roy Roberts, Clark was considered to be an authority on various matters dealing with the population of Kansas, especially rural issues.

In addition, Clark had to answer many inquiries from the proverbial left field. Consider, for example, this letter from a rural Kansas man and Clark's reply (Clark 1933b):
February 20, 1933

Dear Sirs:

Will you kindly inform me of a method of birth control which is harmless but effective. I am a married man 32 years of age. Thanking you in advance.

February 23, 1933

Dear Sir:

I have your letter of February 20th. I am sorry to say that I am unable to advise you concerning a method of birth control because there is a Federal law which makes it a penal offense to send any information on this subject through the mail. However, there are certain situations permitting a physician to provide such information to patients. I suggest that you make inquiry of a reputable physician in your community.

Yours very sincerely,

Carroll D. Clark

\section{CLARK AND "THIS STRANGE CALLING"}

The notion of the calling has recently regained the interests of sociologists. Wolfe (1990) notes the possibility of normlessness in the discipline in regards to professional responsibility. He states that during the 1950 s, when sociology attempted to model itself on the natural sciences, the "vocational ideals" which characterized the discipline reflected some of the same assumptions made by the natural science model. Consequently, the profession began to emphasize the notion of objectivity. "Social scientists could attempt to be objective, even if social science could not" (Wolfe 1990, p. 137). With the advent of feminist and postmodern challenges to the existing paradigms, Wolfe believes that sociologists must find a flexible and contextuai set of professional standards (Wolfe 1990).

Similarly, Lechner (1990) is concerned about the "mindless professionalism" which he feels is threatening the discipline. The meaning of sociology as a vocation for Lechner has less to do with generating new knowledge, which is never truly lasting, than with the process of illuminating the social world. "Sociology... is a social practice that embodies certain virtues. The very effort to understand others, and ourselves, well is one of these virtues" (Lechner 1990, p. 45).

This paper has attempted to show what sociology as a vocation meant to Carroll Clark. At various times in his career, Clark himself referred to sociology as a vocation, a stewardship and a calling. Considering his white, rural Protestant background, which was not an uncommon background for early sociologists, it is not surprising that he approached with a great deal of passion the aspects of his occupation which he felt could make a difference in 
society. For Clark, sociology seems to have been something of a secular equivalent to a religious calling.

Clark felt a deep sense of responsibility to the university, the department and most of all to his colleagues. Warriner recalls that even though Clark expected his colleagues to be intellectually productive, he did not exert excessive pressure on them to produce publications. This type of support, which reflected the more relaxed attitudes towards publishing in that era, allowed his colleagues to feel free to engage in long-term research projects. And even though Clark was constrained by limited budgets (Clark and Noel Gist once completed a large field-work project on the rural population of Kansas with a budget of \$50), Clark did his best to help his colleagues develop as researchers and intellectuals (Gist 1968).

Early in his career, Clark became familiar with the work of Max Weber. Though Clark was not considered by himself or others to be a theorist, he recognized the importance of theory to the discipline. Curiously, a 1935 letter from Clark to an editor at Doubleday Publishers foreshadows the influence that Weber was to have on American sociology. The editor had written Clark to see if he would be interested in seeing more of Weber's work (besides The Protestant Ethic and the Spirit of Capitalism) translated into English.

Personally I should very much like to see Max Weber's works made available in English. I believe he is a very important thinker and that interest in him is likely to grow, especially in view of the crisis now confronting modern capitalism. I believe that such translations would awaken a good deal of interest among scholars, much as Pareto's work is doing. However, whether there would be much response from the general public I would hesitate to say. I am not sufficiently familiar, myself, with the untranslated German works (Clark 1935).

Thus, early in his career Clark was familiar with Weber and was also familiar with the concept of the calling. In Weber's famous essay on "Science as a Vocation," he speaks of the "personal experience of science:"

Without this strange intoxication, ridiculed by every outsider; without this passion, this 'thousands of years must pass before you enter into life and thousands more wait in silence'--according to whether or not you succeed in making this conjective; without this, you have no calling for science and you should do something else. For nothing is worthy of man as man unless he can pursue it with passionate devotion (Weber 1946, p. 135).

Without question, Clark was passionately devoted to his work. He felt that it was his responsibility to communicate the insights of social science to the general public, as well as to contribute to public discourse on social issues. This paper has described some of Clark's passion for the craft of sociology, and what sociology as a vocation meant to him. The wide-ranging contribu- tions made by Clark to the sociology department, the university, and to the region cannot adequately be expressed here. Nevertheless, the legacy of Carroll Clark shows that, indeed, sociology can be a road worth taking.

\section{ENDNOTES}

1. See the Kansas Joumal of Sociology, Volume IV (1968), Issue 1. The introduction to this issue, dedicated to Carroll Clark, was written by the Graduate Students in Sociology at the University of Kansas: "He [Clark] has not only shown us a road to follow, but also has given us hope that it is a road worth taking."

2. Blackmar was the ninth president of the American Sociological Society. He was the founder of the sociology department, the first dean of the Graduate School, and a major figure in the history of the University of Kansas. See Sica (1983, 1990), Fritz (1990) and Clark (n.d, 1965a, 1965b, 1968) for more on the career of Blackmar and the early days of the Kansas department.

3. See Clifford S. Griffin's excellent history of the University of Kansas (1974) for insight into how the structure of the university has changed over the decades.

\section{REFERENCES}

Clark, Carroll D. n.d. "Synopsis of Development of Sociology at the University of Kansas." Memorandum covering the period 1883-1943 prepared for Alpha Kappa Delta and for private circulation. University of Kansas, University Archives. Carroll DeWitt Clark Papers. Box 5, Folder 26. 1926a. "The Small Town Press Sells Out." The New Republic January 20. University of Kansas, University Archives. Carroll DeWitt Clark Papers. Box 3, Folder 31.

1926b. Letter to William Allen White. February 22. University of Kansas, University Archives. Carroll DeWitt Clark Papers. Box 3, Folder 31.

1926c. Letter to Harold Hammond. February 11. University of Kansas, University Archives. Carroll DeWitt Clark Papers. Box 3, Folder 31. 1929a. Letter to Stuart A. Queen. November 18. University of Kansas, University Archives. Carroll DeWitt Clark Papers. Box 1, Folder 1. 1929b. Letter to Stuart A. Queen. November 28. University of Kansas, University Archives. Carroll DeWitt Clark Papers. Box 1, Folder 1.

. 1931. Letter to Ellsworth Faris. January 29. University of Kansas, University Archives. Carroll DeWitt Clark Papers. Box 1, Folder 9. . 1932. Letter to Chancellor E. H. Lindley. July 18. University of Kansas, University Archives. Carroll DeWitt Clark Papers. Box 1, Folder 26. 
Mid-American Review of Sociology

. 1933a. "Yellow Journalism as a Mode of Urban Behavior." Southwestern Social Science Quarterly 14:238-45.

1933b. Letter From Rural Kansas Man and Reply. February 20 and

23. University of Kansas, University Archives. Carroll DeWitt Clark Papers. Box 1, Folder 10.

1933c. Letter to Stuart A. Queen. May 23. University of Kansas

Archives. Carroll DeWitt Clark Papers. Box 1, Folder 10.

1934. "News: A Sociological Study." Abstract of Theses in Humanistic

Series, University of Chicago Press, 9:241-7. 1935. Letter to Ken McCormick. May 20. University of Kansas,

University Archives. Carroll DeWitt Clark Papers. Box 1, Folder 11.

. 1952. "Citizenship." University of Kansas, University Archives. Carroll

DeWitt Clark Papers. Box 1, Folder 3.

1954. "Sociology on the Air." University of Kansas, University

Archives. Carroll DeWitt Clark Papers. Box 1, Folder 3. 1959. "A Professor Looks at Jazz." University of Kansas, University

Archives. Carroll DeWitt Clark Faculty File.

1962. "Sociology and the Midwest in the Perspective of Twenty-Five

Years." The Sociological Quarterly 3(1):267-77.

. 1965a. "Launching Anthropology at KU." Mimeograph. Lawrence,

Kansas: University of Kansas.

. 1965b. "History of the Sociology Department: The University of

Kansas, 1889-1965." Kansas Joumal of Sociology 1(3):90-101. 1968. "My Sociological Stewardship: Part I." Kansas Joumal of

Sociology 4(1):5-36.

. 1970. "Vignettes from a Rural Life History: A Prologue to My

Sociological Stewardship." Kansas Joumal of Sociology 6(3):107-132.

1974. Notes on Mabel Elliot. University of Kansas, University Archives. Carroll DeWitt Clark Papers. Box 1, Folder 29.

Clark, Carroll D. and Roy L. Roberts. 1936. People of Kansas: A Demographic and Sociological Study: Topeka: Kansas State Planning Board.

Eldridge, Seba, and Carroll D. Clark. 1928. Major Problems of Democracy. New York: Century Company.

Fritz, Jan M. 1990. "Notes From the History of American Sociology: Frank Blackmar's Last Years at the University of Kansas." Mid-American Review of Sociology 14(1-2):13-26.

Gist, Noel P. 1968. "Some Retrospective Musings." Kansas Joumal of Sociology 4(1):37-40.

Goldsen, Rose K. 1964. "Mills and the Profession of Sociology." Pp. 88-93 in The New Sociology, edited by Irving Louis Horowitz. New York: Oxford.

Griffin, Clifford S. 1974. The University of Kansas: A History. Lawrence, Kansas: University of Kansas Press.

Jacoby, Russell. 1987. The Last Intellectuals: American Culture in the Age of Academe. New York: Basic Books.

Lechner, Frank J. 1990. "Sociology as a Vocation." The American Sociologist 21(1):41-47.

\section{A Road Worth Taking}

indley, Ernest. 1932 Memorandum to Carroll Clark. September 13. University of Kansas, University Archives. Carroll DeWitt Clark Papers. Box 1, Folder 26.

McCluggage, Marston. 1968. "To Carroll D. Clark." Kansas Journal of Sociology 4(1):i-iv.

Mills, C. Wright. 1963. "The Social Role of the Intellectual." Pp. 292-304 in Power, Politics and People: The Collected Essays of C. Wright Mills. New York: Oxford.

Park, Robert E. 1933. Letter to Carroll Clark. January 10. University of Kansas, University Archives. Carroll DeWitt Clark Papers. Box 1, Folder 10.

Patterson, Shirley, and Ben Zimmerman, eds. 1987. Transitions: The Emergence, Growth and Development of the School of Social Welfare. Lawrence, Kansas: University of Kansas Printing Services.

Queen, Stuart A. 1929. Letter to Carroll Clark. November 5. University of Kansas, University Archives. Carroll DeWitt Clark Papers. Box 1, Folder 1.

1930. Letter to Carroll Clark. June 28. University of Kansas, University Archives. Carroll DeWitt Clark Papers. Box 1, Folder 1.

Sica Alan. 1983. "Sociology at the University of Kansas, 1889-1983: An Historical Sketch." The Sociological Quarterly 24 (Autumn):605-623.

1990. "A Question of Priority: Small at Chicago or Blackmar at Kansas?" Mid-American Review of Sociology 14(1-2):1-12.

Weber, George H. 1968. "Reflections on Dr. Clark's Teaching and Applied Sociology." Kansas Joumal of Sociology 4(1):41-46.

Weber, Max. 1946. From Max Weber: Essays in Sociology. Edited by H.H. Gerth and C. Wright Mills. New York: Oxford.

White, William Allen. 1926. Letter to Carroll Clark. March 12. University of Kansas, University Archives. Carroll DeWitt Clark Papers. Box 3, Folder 31.

Wolfe, Alan. 1990. "Sociology as a Vocation." The American Sociologist $21(2): 136-149$. 


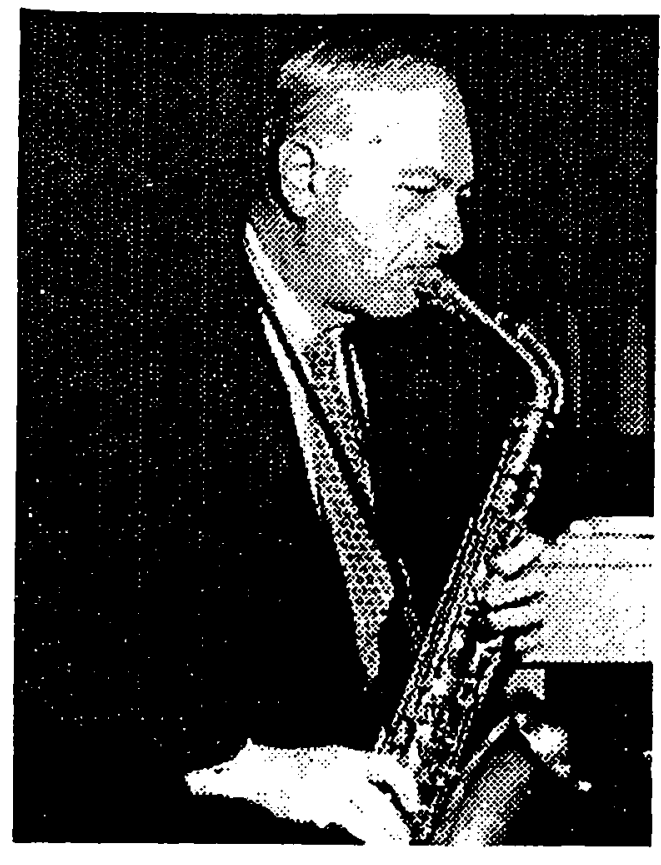

Dr. Carroll Clark, Chair of the Department 1931-1962.

Renowned for his saxophone playing at ASA meetings and local radio shows.

Dr. E. Jackson Baur joined the faculty in 1947. He is now Professor Emeritus. Department Chair 1970-1973.

\section{STREETCORNER SOCIOLOGY}

\section{Jean Van Delinder}

University of Kansas

Mid-American Review of Sociology, 1991, Vol. XV, No. 2:59-69

Sociology at the University of Kansas is steeped in the ethnographic tradition of the "Chicago School." This is the result of a continuous exchange of promising graduate students and faculty between the two departments. Dr. E. Jackson Baur is a part of the "Chicago connection." He was awarded the Ph.D. by Chicago in 1942 and was hired as an Assistant Professor by the University of Kansas in 1947. He has been Professor Emeritus since 1983 and still maintains an active involvement in the department. The following is an informal history of Dr. Baur's experiences as a student at Chicago and as a professor at Kansas.

Sociology at the University of Kansas has been predominately "humanistic." Frank W. Blackmar, the original chair and founder of the department addresses such topics in his prolific writings on Spanish Institutions of the Southwest (1891), Spanish Colonization in the Southwest (1890), and Social Degeneration in Towns and Rural Villages $(1900){ }^{2}$ As director of the "Social Surveys Series," Blackmar coordinated five ethnographies, two of which Ernest W. Burgess contributed to. Burgess conducted his first ethnographic community studies in Lawrence before accepting an appointment in Chicago in 1915. Through the use of surveying techniques Burgess studied "the social conditions" of Belleville and Lawrence, Kansas (Sica 1983, p. 609). Thirty-two years later, Dr. E. Jackson Baur was recruited to the University of Kansas because of his skills in survey research and community studies. Baur conducted numerous studies involving surveys and opinion polls on topics ranging from teenage drinking habits to attitudes of farmers toward construction of a dam that would alter their communities.

"Streetcorner sociology," though prolific at Chicago, was also common in Kansas. There was a long standing tradition for promising graduate students to complete the Ph.D. at Chicago rather than Kansas. In return, several Chicago faculty members have been recruited to the University of Kansas Sociology Department. The tradition of using the community as a workshop is evident from a quick perusal of M.A. and Ph.D. topics: "A Survey of the Fraternity Situation at Kansas University" (1916), "Comerio; a Sociological Study of an Island Puerto Rican Town" (1936), "A Social Study of a CCC Camp" (1938), "Small Town in Modern India" (1969). ${ }^{3}$

Dr. E. Jackson Baur is a sociologist trained at Chicago and a member of the Kansas faculty for forty-four years. As part of the Sociology Department's Centennial Celebration in the Spring of 1991, I interviewed Dr. Baur about his tenure as a graduate student and his professional career at Kansas. As much as possible, I will let Dr. Baur speak for himself. 